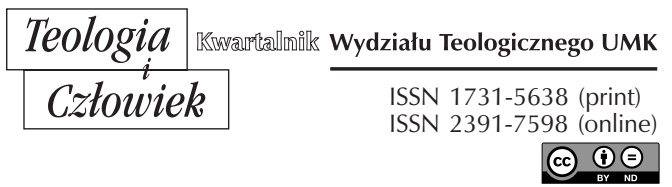

47(2019)3, ss. $11-32$

BP ANDRZEJ F. DZIUBA

UNIWERSYTET KARDYNAŁA STEFANA WYSZYŃSKIEGO W WARSZAWIE

REZYDENCJA@DIECEZJA.LOWICZ.PL

ORCID: 0000-0002-3845-5364

\title{
EKLEZJALNE ZNAMIONA ŻYCIA KONSEKROWANEGO
}

DOI: http://dx.doi.org/10.12775/TiCz.2019.027

Streszczenie. Życie konsekrowane to oddanie swego życia na służbę Bogu dla dobra Kościoła. Dlatego ważne jest dostrzeganie eklezjalnego znamienia tej drogi życiowej. To konsekracja określa właściwe miejsce osób konsekrowanych we wspólnocie Kościoła. Przez profesję osoba konsekrowana poświęca się Kościołowi, zobowiązując się do ochotnej służby na wzór Chrystusa, konsekrowanego przez Ojca i posłanego, aby spełnić misję. To powołanie jest także misją Kościoła w świecie, w duchu radykalizmu rad ewangelicznych. To poświęcenie dla chwały Boga, budowanie Kościoła i zbawienia świata z jedoczesnym pragnieniem osiągnięcia doskonałej miłości w służbie Królestwa Bożego.

Kościół święty zawsze i z uznaniem patrzy na doniosłość życia konsekrowanego. Dotyczy to zarówno przeszłości, jak i teraźniejszości, a jednocześnie także nadziei ku przyszłości. To nie tylko dzieła i znaki posługi, ale przede wszystkim współtworzenie Kościoła, w ramach trzech stanów. To jest de facto współkonstytuowanie Kościoła, bo życie konsekrowane przynależy do jego struktury. Ma w nim źródło, istnienie i ostatecznie jest dla Kościoła. Będąc z Kościoła, w Kościele i dla Kościoła stan życia konsekrowanego powołany jest do życia duchowością komunii „sentire cum Ecclesia”.

Słowa kluczowe: życie konsekrowane; Kościół; „sentire cum Ecclesia”; akt konsekracji; „Vita consecrata”; rady ewangeliczne.

Summary. Ecclesiastical Traces of Consecrated Life. Consecrated Life means surrendering one's life to God's ministry for the good of the Church. It is important to notice the ecclesiastical dimension of this way of life. Consecration defines the proper 
place of the consecrated person in the community of the Church. Through the very act of consecration, one dedicates one's life to the Church and expresses willingness to perform the ministry according Christ's example, who was consecrated by the Father and sent to carry out His will. This call is also the mission of the Church in the world, in the spirit of the radical life of evangelical counsels. This consecration aims at the greater glory of God, at the building of the Church and at the salvation of the world, with the desire to attain perfect life in God's kingdom.

The Church has always very highly respected consecrated life - it refers both to the past and to the future and is always directed to the future. Consecrated people carry out multiple and various ministries endowed with graces from above to build the Church. Consecrated life is part of the very structure of the Church. This kind of life has in the Church its source and its existence, and it exists for the good of the Church. Being from the Church and in the Church, consecrated people are called to live in the spirit of community, expressed in Latin ad "sentire cum Ecclesia" (to think and feel with the Church).

Key words: consecrated Life; the Church; "sentire cum Ecclesia"; act of consecration; "Vita consercata"; evangelical counsel.

Postrzeganie życia konsekrowanego zawsze wymaga odniesienia do Kościoła. Jest to bowiem dar dla całego Kościoła. To Kościół go otrzymał i rozwinął. To oddanie swego życia na służbę Bogu dla dobra Kościoła. Chodzi o poświęcenie się całkowite, płynące z umiłowania Boga ponad wszystko ${ }^{1}$. Zatem byłoby błędem postrzeganie go jako „Kościoła w Kościele”, jakąś szczególną specyfikę życia, która mimo że jest niedostępna dla wszystkich, to jednak stanowi specyficzny znak czy cząstkę Kościoła. Dlatego wydaje się, że warto spojrzeć jeszcze raz na eklezjalne znamiona czy eklezjalny rys życia konsekrowanego.

Kościół Mistyczne Ciało Chrystusa, ale także wspólnota ludu Bożego, w której można wskazać trzy wielkie stany życia: świeccy, duchowni i osoby życia konsekrowanego. To powołania do życia w świecie w małżeństwie lub samotności, do kapłaństwa służebnego oraz do specyficznego życia przez profesję rad ewangelicznych ${ }^{2}$. Konsekracja określa właściwe miejsce osób konsekrowanych w rozległej wspólnocie Kościoła. Przez profesję osoba konsekrowana poświęca się Kościołowi, zobowiązując

1 Por. KK 44

2 Por. Jan Paweł II, List do Młodych Parati semper, Città del Vaticano 1985, nr 9; Kongregacja Instytutów Życia Konsekrowanego i Stowarzyszeń Życia Apostolskiego, Rozpocząć na nowo od Chrystusa. Odnowione zaangażowanie życia konsekrowanego w trzecim tysiącleciu. Instrukcja, Poznań 2002, nr 22. 
się do ochotnej służby na wzór Chrystusa, konsekrowanego przez Ojca i posłanego, aby spełnić misję.

To powołanie jest także misją Kościoła w świecie. Trzeba pamiętać, że każdy chrześcijanin jest powołany do życia według rad ewangelicznych i wypływa to z faktu chrztu, bierzmowania, sakramentu kapłaństwa czy sakramentu małżeństwa. Natomiast w życiu konsekrowanym chodzi o profesję życia według radykalizmu rad ewangelicznych w Kościele. To poświęcenie dla chwały Boga, budowanie Kościoła i zbawienia świata z jedoczesnym pragnieniem osiągnięcia doskonałej miłości w służbie Królestwa Bożego, stając się jednocześnie w Kościele wyraźnym znakiem, zapowiadającym niebieską chwałę ${ }^{4}$.

\section{DONIOSŁOŚĆ ŻYCIA KONSEKROWANEGO W ŻYCIU KOŚCIOŁA}

Fundamentalne wydaje się stwierdzenie, że „życie konsekrowane, głęboko zakorzenione w przykładzie i nauczaniu Chrystus Pana, jest darem Boga Ojca udzielony Jego Kościołowi za sprawą Ducha Świętego"5. Zatem jest to szczególny radykalizm naśladowania Chrystusa, który przyczynia się „do objawienia tajemnicy i misji Kościoła”. Ten radykalizm związany z naśladowaniem ,jest źródłem, wzorem o mocą świadectwa, jakie składa uczeń, powołany by iść tą samą drogą: "Jeśli kto chce iść za Mną, niech się zaprze samego siebie, niech co dnia bierze krzyż swój i niech Mnie naśladuje» (Łk 9,23)"7.

Jest to wielkie i zróżnicowane bogactwo realizacji tego specyficznego powołania, które dotyka także innych tradycji chrześcijańskich ${ }^{8}$. W różnych

3 Por. tenże, Adhortacja apostolska Redemptoris donum, Città del Vaticano 1984, nr 7; tenże, Adhortacja apostolska Vita consecrata, Città del Vaticano 1996, nr 76; tenże, Adhortacja apostolska Catechesi tradendae, Città del Vaticano 1979, nr 65.

${ }^{4}$ Por. KK 44; F. Ciardi, Spunti di lettura ecclesiologica della „Vita consecrata”, w: Vita consecrata. Una prima lettura teologica, Milano 1996, s. 55-105.

${ }_{5}^{5}$ Jan Paweł II, Adhortacja apostolska Vita consecrata, nr 1.

6 Tenże, Adhortacja apostolska Vita consecrata, nr 1.

7 Tenże, Encyklika Veritatis splendor, Città del Vaticano 1993, nr 89. Por. tenże, Adhortacja apostolska Reconciliatio et paenitentia, Città del Vaticano 1984, nr 4; D. Mongillo, Stałe nawrócenie i asceza. Ponowne odkrycie i nowa ocena terminów, w: Perspektywy i problemy teologii moralnej, red. G. Angelini i inni, Warszawa 1982, s. 167-181.

8 „Wszyscy zdajemy sobie sprawę, jakim bogactwem jest dla wspólnoty kościel- 
nurtach rozrasta się rzesza tych, którzy wybrali Chrystusa, idąc drogą radykalizmu ewangelicznego i braterskiej miłości. Oni są szczególnie wrażliwi na wezwanie do pokuty i nawrócenia ${ }^{9}$. Ważne są także działania na rzecz przezwyciężania podziałów, które są przeszkodą ewangelizacyjną ${ }^{10}$.

Ten dar, to niepowtarzalne bogactwo życia konsekrowanego przynależy do samej rzeczywistości Kościoła. Dlatego wskazuje się wyraźnie, że „życie konsekrowane znajduje się w samym sercu Kościoła jako element o decydującym znaczeniu dla jego misji, ponieważ «wyraża najgłębszą istotę powołania chrześcijańskiego», oraz dążenie całego Kościoła-Oblubienicy do zjednoczenia z jedynym Oblubieńcem"11. Ten radykalny dar z siebie dla Chrystusa oraz ludzi jednocześnie pozostaje na zawsze „pomocą i oparciem dla Kościoła”"12, zwłaszcza wobec tych, którzy pozornie znają Chrystusa, ale żyją daleko od Niego i Jego Kościoła ${ }^{13}$.

Zatem życie konsekrowane ma swoją rangę i nie wynika to np. tylko z jego funkcji, drogi powołania do świętości czy misji ewangelizacyjnej, ale $\mathrm{z}$ samej struktury Kościoła ${ }^{14}$. To dopiero pozwala na poznanie ojcowskiego oblicza Boga i macierzyńskiego oblicza Kościoła. Dopiero życie konsekrowane „jest dzisiaj tak samo jak w przeszłości cenną ozdobą Domu Bożego, czyli Kościoła”"15. Zawsze jednak pamiętając o zróżnicowaniu i komunii trzech stanów życia, bo one wpisane są w Ko-

nej dar życia konsekrowanego w całej różnorodności jego charyzmatów i instytucji” (Jan Paweł II, Adhortacja apostolska Vita consecrata, nr 2).

9 Por. tenże, Encyklika Ut unum sint, Città del Vaticano 1995, nr 15, 33-35.

${ }_{10}$ Por. tenże, Adhortacja apostolska Ecclesia in Europa, Città del Vaticano 2003, nr 30.

11 Tenże, Adhortacja apostolska Vita consecrata, nr 3. Por. B. Kruszyłowicz, Wymiar eklezjalny życia konsekrowanego, w: Communio consecrata, red. K. Wójtowicz, Kraków 2002, s. 116-125; P. Liszka, Charyzmatyczna moc życia zakonnego, Wrocław 1996, s. 95-105; C. Parzyszek, Przesłanie Jana Pawła II o życiu konsekrowanym, „Ateneum Kapłańskie” 149 (2007), z. 1 (590), s. 69-70.

12 Jan Paweł II, Adhortacja apostolska Vita consecrata, nr 3.

13 Por. tenże, Encyklika Redemptoris missio, Città del Vaticano 1990, nr 33; J. Weismayer, Petnia życia. Zarys historii i teologii chrześcijańskiej duchowości, Kraków 1993, s. 7-9.

14 „Kościół pod żadnym pozorem nie może wyrzec się życia konsekrowanego, ponieważ ukazuje ono wyraziście jego szczególną naturę "oblubieńczą»" (Jan Paweł II, Adhortacja apostolska Vita consecrata, nr 105).

15 Tenże, Adhortacja apostolska Vita consecrata, nr 104. 
ściół i jego misję $e^{16}$ Z drugiej strony istnieje powszechne powołanie do świętości ${ }^{17}$.

Życia konsekrowane jawi się w swej wielkiej dynamice darów Ducha Świętego. Zatem drogi wspólnotowe, zwłaszcza monastyczne i instytuty świeckie, oraz indywidulane. Tutaj wybrzmiewa natura i misja Chrystusowego Kościoła, która bogata jest jego stanami ${ }^{18}$. Kościół, dzięki temu, że jest „znakiem i narzędziem obecności i działania Ducha Ożywiciela”, staje się przewodnikiem ludzkich sumień, bo mocą tegoż Ducha Świętego „Dobra Nowina przyobleka się w ciało ludzkich serc i sumień i rozszerza się w historii”"19.

Trzeba zawsze pamiętać, że „ludzie świeccy ze względu na świecką naturę swego powołania odzwierciedlają tajemnicę Bożego Słowa przede wszystkim jako Tego, który jest Alfą i Omega świata, podstawą i miarą wartości wszystkich rzeczy stworzonych. Z kolei ci, którzy otrzymali święcenia, są żywym wizerunkiem Chrystusa - Głowy i Pasterza, prowadzącego swój lud, który wędruje przez rzeczywistość doczesną, pomiędzy «już» a «jeszcze nie», w oczekiwaniu na Jego przyjście w chwale. Zadanie powierzone życiu konsekrowanemu polega na ukazywaniu, że Wcielony Syn Boży jest eschatologicznym celem, ku któremu wszystko zmierza, blaskiem, przy którym blednie wszelkie inne światło, nieskończonym pięknem, które samo zdolne jest zaspokoić wszystkie pragnienia ludzkiego serca”20. Przecież „śmierć może być źródłem życia i miłości”21.

${ }_{16}$ Por. tenże, Adhortacja apostolska Vita consecrata, $\mathrm{nr} 4$

17 Por. KK 31; KDK 52; Jan Paweł II, Adhortacja apostolska Christifideles laici, Città del Vaticano 1988, nr 16-17.

18 Por. tenże, Adhortacja apostolska Vita consecrata, nr 8, 12.

19 Tenże, Encyklika Dominum et Vivificantem, Città del Vaticano 1986, nr 64.

${ }^{20}$ Tenże, Adhortacja apostolska Vita consecrata, nr 16. „Jaką postawę przyjąć w obliczu śmierci? Człowiek wierzący wie, że jego życie jest w ręku Boga: «Ty, Panie, mój los zabezpieczasz» (por. Ps 16(15),5) i godzi się przyjąć od Niego także śmierć: «Taki jest wyrok wydany przez Pana na wszelkie ciało: i po co odrzucać to, co się podoba Najwyższemu» (Syr 41,4). Człowiek nie jest panem śmierci, tak jak nie jest panem życia; w życiu i w śmierci musi zawierzyć się całkowicie "woli Najwyższego», zamysłowi Jego miłości” (tenże, Encyklika Evangelium vitae, Città del Vaticano 1995, nr 46).

${ }^{21}$ Tenże, Encyklika Fides et ratio, Città del Vaticano 1998, nr 23. „Śmierć jest czymś całkowicie innym niż doświadczenie beznadziejności: jest bramą istnienia otwartą na wieczność, a dla przeżywających ją w Chrystusie uczestnictwem w Jego tajemnicy śmierci i zmartwychwstania" (tenże, Encyklika Evangelium vitae, nr 97). 


\section{2. "W KOŚCIELE I DLA KOŚCIOŁA"}

Życie konsekrowane strukturalnie przynależy do pojęcia Kościoła Chrystusowego. Profesja rad ewangelicznych i życie według radykalizmu tych rad przynależy do „życia i świętości Kościoła”22. W sensie osobowym chodzi o „wysoką miarę" zwyczajnego życia ochrzczonych ${ }^{23}$. Prawda ta opiera się na woli samego Chrystusa, a On dopiero w pełni objawia człowieka samemu człowiekowi ${ }^{24}$. To On sam powoływał pewne osoby do radykalizmu życia, wskazując jego eschatyczną wartość. Toteż „wizja Kościoła złożonego wyłącznie z szafarzy i z wiernych świeckich nie odpowiada zamiarom jego Boskiego Założyciela, jakie możemy odczytać z Ewangelii i z innych pism Nowego Testamentu"25. Zresztą Kościół rodzi i wychowuje do powołania przez głoszenie słowa Bożego, sprawowanie sakramentów oraz służbę i świadectwo miłości ${ }^{26}$.

Można powiedzieć, że życie konsekrowane ma swe praźródło w chrzcie św., a więc znaku wejścia do Kościoła, stajemy się „członkami Chrystusa i członkami Ciała Kościoła”27. Ten sakrament stawia wymaganie właściwej dla swego stanu czystości. Oczekuje posłuszeństwa wobec Boga i Kościoła oraz odpowiedniego dystansu wobec dóbr materialnych. Z tym wszystkim oczywiście łączy się powszechne powołanie do świętości, które odnosi się do każdego ochrzczonego. Do tej drogi w Kościele z czasem dochodzi sakrament bierzmowania jako pogłębienie konsekracji chrzcielnej ${ }^{28}$. Ze świętością osobistą wiąże się postawa świadectwa wiary

${ }^{22}$ KK 44. „Znaczy to, że życie konsekrowane, obecne w Kościele od samego początku, nigdy nie zniknie jako jego niezbywalny i konstytutywny element, ponieważ wyraża samą jego naturę" (Jan Paweł II, Adhortacja apostolska Vita consecrata, nr 29).

${ }^{23}$ Por. tenże, List apostolski Novo millennio ineunte, Città del Vaticana 2001, nr 31.

24 Por. tenże, Encyklika Redemptor hominis, Città del Vaticano 1979, nr 10; tenże, Encyklika Dives in misericordia, Città del Vaticano 1980, nr 1; tenże, Encyklika Fides et ratio, nr 60.

25 Tenże, Adhortacja apostolska Vita consecrata, nr 29.

${ }^{26}$ Por. tenże, Adhortacja apostolska Pastores dabo vobis, Città del Vaticano 1992, nr 35 .

${ }^{27}$ DS 1314.

${ }^{28}$ „Przez sakrament bierzmowania jeszcze doskonalej wiążą się z Kościołem i obdarzani są szczególną mocą Ducha Świętego, i w ten sposób jeszcze bardziej są zobo- 
oraz zadanie budowania świętości Kościoła i uświęcanie świata, czyli ewangelizacja ${ }^{29}$.

Jednak życie konsekrowane jest jedyną i nową konsekracją, i to $\mathrm{z}$ nowego tytułu. Dwa wspomniane sakramenty nie wymagają bowiem życia w celibacie czy czystości, rezygnacji z posiadania dóbr czy posłuszeństwa przełożonym. Rady ewangeliczne stawiają to zobowiązanie na mocy radykalizmu ich profesji ${ }^{30}$. Jest to nowy Dar Ducha Świętego udzielany tym, którzy mają prowadzić czynne życie chrześcijańskie, podejmując ściślejszą współpracę i służąc Kościołowi, by przez praktykę rad ewangelicznych przynosić nowe i bogatsze owoce świętości i apostolstwa (por. 1 Kor 12; Rz 12,6-8) ${ }^{31}$. Dar ten obejmuje więc najgłębszą istotę ludzką, czyli „moc miłowania, pragnienie posiadania i wolność kierowania sobą ”32.

Zatem stan życia konsekrowanego trzeba rozeznawać w Kościele i dla Kościoła. To znaczy, że ten stan współtworzy Kościół Chrystusowy razem ze stanem świeckim i stanem kapłańskim. To właśnie z woli Chrystusa wszyscy ochrzczeni mają uczestniczyć we „wspólnej godności” i w powołaniu do świętości ku budowaniu Kościoła Chrystusowego. „Powołania do życia świeckiego, do posługi święceń i do życia konsekrowanego mają charakter paradygmatyczny, jako że w taki czy inny sposób wywodzą się z nich lub do nich się odwołują wszystkie powołania szczegółowe" ${ }^{33}$. Oczywiście wszystkie te powołania należy widzieć w Kościele i dla Kościoła ${ }^{34}$.

wiązani, jakom prawdziwi świadkowie Chrystusa, do szerzenia wiary słowem i uczynkiem oraz do jej obrony" (KK 11). Por. KKK 1285.

${ }^{29}$ Por. Jan Paweł II, Adhortacja apostolska Christifideles laici”, nr 29; tenże, Adhortacja apostolska Ecclesia in Africa, Città del Vaticano 1995, nr 74.

${ }^{30}$ Por. tenże, Adhortacja apostolska Vita consecrata, nr 30.

${ }^{31}$ Por. tenże, Wymiary życia konsekrowanego, 26.10.1994, w: Katechezy Ojca Świętego Jana Pawła II. Kościót, Kraków-Ząbki 1999, s. 411-414; Franciszek, Adhortacja apostolska Gaudete et exsultate, Città del Vaticano 2018, nr 11; Jan Paweł II, Encyklika Redemptor hominis, nr 20; J.-F. Collange, De Jésus à Paul: Letique du Nouveau Testament, Genève 1980, s. 227-232; S. Grabska, Comment lire les lettres de Saint Paul pour utiliser son enseignement dans la théologie morale contemporaine, „Studia Moralia” 13(1975), s. $56-60$.

${ }^{32}$ Paweł VI, Adhortacja apostolska Evangelica testificatio, Città del Vaticano 1971, nr 7.

33 Jan Paweł II, Adhortacja apostolska Vita consecrata, nr 31.

34 „Stała obecność Chrystusa przy człowieku każdej epoki urzeczywistnia się 
W tym kontekście osoby życia konsekrowanego powinny odnajdować swą tożsamość w ukazywaniu i uobecnianiu eschatycznym powołania wszystkich ochrzczonych oraz powołanych do zbawienia w Chrystusie ${ }^{35}$. Jest zatem „charakterystyczną, aczkolwiek nie wyłączną cechą [...] osób konsekrowanych - szczególne upodobnienie do Chrystusa czystego, ubogiego i posłusznego" ${ }^{36}$. Warto pamiętać, że stan życia konsekrowanego ma pierwszeństwo w ukazywaniu oblicza świętości Kościoła, a to jest misją Kościoła ${ }^{37}$.

Osoby życia konsekrowanego winna szczególnie charakteryzować ewangeliczna duchowość błogosławieństw ${ }^{38}$. To nie neguje, iż jest to propozycja dla wszystkich ochrzczonych, gdyż takie winno być oblicze Kościoła. Zresztą jest to także bodziec na drodze do doskonałości ${ }^{39}$. Życie konsekrowane, a więc życie według rad ewangelicznych jest stałym na-

w Jego ciele, którym jest Kościół. Dlatego Chrystus obiecał swoim uczniom Ducha Świętego, który miał im "przypomnieć» i wyjaśnić Jego przykazania (por. J 14,26), i stać się źródłem nowego życia w świecie (por. J 3,5-8; Rz 8,1-13)" (tenże, Encyklika Veritatis splendor, nr 25). Por. Franciszek, Encyklika Lumen fidei, Città del Vaticano 2013, nr 38; H. Wattiaux, Engagement de Dieu et fidélité du chrétien. Perspectives pour une théologie morale fondamentale, Louvain-la-Nevue 1979, s. 150-155; W. Bouwmeester, Lalleanza nella Bibbia, Bari 1972, s. 113-117

${ }^{35}$ Por. Jan Paweł II, Encyklika Veritatis splendor, nr 88. „Włączony w Chrystusa, chrześcijanin staje się członkiem jego Ciała, którym jest Kościół (por. 1 Kor 12,13.27). Pod działaniem Ducha Świętego Chrzest w sposób radykalny upodabnia człowieka wierzącego do Chrystusa w paschalnej tajemnicy Jego śmierci i zmartwychwstania, "przyobleka» go w Chrystusa (por. Ga 3,27)" (tenże, Encyklika Veritatis splendor, nr 21). Por. Franciszek, Encyklika Lumen fidei, nr 22; F.-X. Durrwell, „Siete stati chiamati”, w: Chiamati alla liberta. Saggi di teologia morale in onore di Bernard Häring, red. H. Boelaars, R. Tremblay, Roma 1980, s. 7-22; L. F. Ladaria, Antropologia teologica, Roma-Casale Monferrato 1986, s. $435-440$.

${ }^{36}$ Jan Paweł II, Adhortacja apostolska Vita consecrata, nr 31.

37 Por. tamże, nr 32.

38 „Błogosławieństwa znajdują się w centrum przepowiadania Jezusa. Ich ogłoszenie podejmuje obietnice dane narodowi wybranemu od czasów Abrahama. Wypełnia je, wskazując za ich pośrednictwem na tylko na korzystanie z dóbr ziemskich, ale na Królestwo niebieskie" (KKK 1716). Por. KDL 72; KK 31.

39 Por. Jan Paweł II, Adhortacja apostolska Vita consecrata, nr 33. „Powołanie ludzi świeckich do świętości oznacza wezwanie do tego, by żyli oni wedle Ducha włączeni w rzeczywistość doczesna i poprzez uczestnictwo w działalności ziemskiej” (tenże, Adhortacja apostolska Christifideles laici, nr 17). 
śladowaniem Chrystusa czystego, ubogiego i posłusznego ${ }^{40}$. Tym samym wpisują się one w tajemnicę Odkupienia, której centrum tkwi w paschalnym Jezusie Chrystusie, będącym źródłem nowego stworzenia.

Radykalizm ewangeliczny objawiony w życiu osób konsekrowanych wyrasta z przekonania, że „Ewangelia przedstawia ideał konsekracji osoby, czyli wyłącznego poświęcenia człowieka Bogu na podstawie rad ewangelicznych, a zwłaszcza rady czystości, ubóstwa i posłuszeństwa. Najdoskonalszym ich wcieleniem jest sam Jezus Chrystus. Kto pragnie iść za Nim w sposób radykalny, wybiera życie wedle tych rad. Różnią się one od przykazań i wskazują dla chrześcijanina drogę radykalizmu ewangelicznego" 41 .

Zatem będąc z Kościoła i w Kościele, życie konsekrowane szczególnie doświadcza swej tożsamości w służbie Kościołowi, a przez niego w służbie ludziom ${ }^{42}$. Służba Kościołowi winna praktycznie przekładać się na pozytywne budowanie komunii w swojej wspólnocie życia konsekrowanego oraz szeroko pojętnej komunii eklezjalnej. „Komunia rodzi komunię i w samej swej istocie przyjmuje kształt misyjny"43. To jest sięganie do obrazu komunii trynitarnej w świecie, a winno pobudzać solidarność międzyludzką i kulturę życia wspólnotowego według normy miłości ${ }^{4}$. „Duchowość komunii to przede wszystkim spojrzenie utkwione w tajemnicy Trójcy Świętej, która zamieszkuje w nas i której blask należy dostrzegać także w obliczach braci żyjących wokół nas" ${ }^{45}$.

Poprzez wymianę $\mathrm{z}$ innymi i wzajemną służbę człowiek rozwija swoje możliwości, odpowiadając w ten sposób na Boże powołanie ${ }^{46}$. „Cały Kościół liczy bowiem bardzo na świadectwo wspólnot, które napełnia «wesele i Duch Święty» (Dz 13,52). Kościół chciałby ukazywać światu przykłady wspólnot, w których wzajemna troska pomaga przezwyciężyć

40 Por. tenże, Adhortacja apostolska Vita consecrata, $\mathrm{nr} 34$.

${ }^{41}$ Tenże, List apostolski Mulieris dignitatem, Città del Vaticano 1988, nr 20.

42 „Ten Duch prowadzi wspólnoty życia konsekrowanego ku wypełnieniu ich misji w służbie Kościołowi i całej ludzkości, zgodnie z ich własną pierwotną inspiracją" (tenże, Adhortacja apostolska Vita consecrata, nr 42).

${ }_{43}$ Tenże, Adhortacja apostolska Christifideles laici, nr 32.

${ }^{44}$ Por. tenże, Adhortacja apostolska Vita consecrata, nr 42.

45 Tenże, List apostolski Novo millennio ineunte, nr 43.

${ }^{46}$ Por. KKK 1879. 
samotność, więź braterska budzi we wszystkich współodpowiedzialność, a przebaczenie zabliźnia rany, umacniając w każdym dążenie do komunii” ${ }^{47}$. Kościół zawsze winien być „prawdziwym miejscem i narzędziem komunii”"48.

Podejmowane we właściwy sposób, „błogosławieństwa stawiają nas wobec decydujących wyborów dotyczących dóbr ziemskich; oczyszczają nasze serca, by nas nauczyć miłować Boga nade wszystko” ${ }^{49}$. Dlatego, „aby ukazać współczesnym ludziom swoje prawdziwe oblicze, Kościół pilnie potrzebuje takich wspólnot braterskich, które samym swoim istnieniem wnoszą wkład w nową ewangelizację, ponieważ w konkretny sposób ukazują owoce «nowego przykazania»" 50 . Zresztą życie pokazuje, że „człowiek nie może być prawdziwie wolny, jak tylko przez miłość. Miłość Boga nade wszystko i miłość ludzi: braci, bliźnich, rodaków"51.

\section{SENTIRE CUM ECCLESIA}

Eklezjalna świadomość ludzi życia konsekrowanego zawsze powinna być nastawiona na wartość bycia z Kościołem, w Kościele i dla Kościoła, co winno także mieć swój czytelny wyraz w eklezjalnym charakterze pełnionej misji. Podkreślić należy, że ,już na płaszczyźnie istnienia, czyli wcześniej, aniżeli na płaszczyźnie działania, chrześcijanie są latoroślami jednego krzewu winnego - Chrystusa, są żywymi członkami jednego Ciała Pańskiego, zbudowanego na mocy Ducha Świętego"52. Komunia eklezjalna jest istotna dla samej doskonałości Kościoła, a wobec świata znakiem jego wiarygodności ${ }^{53}$. Tym bardziej że „istnieje pewne podobieństwo między

47 Jan Paweł II, Adhortacja apostolska Vita consecrata, nr 45. Por. R. Bultmann, Theologie des Neuen Testaments, Tübingen 1977, s. 156-159; R. Tremblay, L’,innalzamento” del Figlio, fulcro della vita morale, Roma 2001, s. 29-33.

48 Jan Paweł II, Adhortacja apostolska Ecclesia in Europa, nr 28.

${ }^{49}$ KKK 1728.

50 Jan Paweł II, Adhortacja apostolska Vita consecrata, nr 45.

51 Tenże, Trudny dar wolności. Homilia podczas Mszy św. w kaplicy Cudownego Obrazu, Częstochowa. 13.06.1987, „L'Osservatore Romano” 8 (1987), nr 5 bis, s. 9.

52 Tenże, Adhortacja apostolska Christifideles laici, nr 55.

${ }^{53}$ „Zamysł kościelnej komunii, rozwijając się w duchowość komunii, kształtuje sposób myślenia, mówienia i działania, który sprawia, że Kościół rozrasta się w głąb 
jednością Osób Boskich a braterstwem, jakie ludzie powinni zaprowadzać między sobą, w prawdzie i miłości” ${ }^{54}$.

Można zauważyć „szczególne dary i zdolności”, którymi Duch Święty ubogaca Kościół: mogą one „przybierać najrozmaitsze formy, już to jako wyraz najpełniejszej wolności Ducha, który jest ich dawcą, już to jako odpowiedź na różnorodne wymogi pojawiąjące się w dziejach Kościoła" ${ }^{5}$. Wszystko jako obecność owoców Ducha: miłości, radości, pokoju (por. Ga 5,22) ku budowaniu komunii (por. 1 Kor 14,26) ${ }^{56}$. Ów „zmysł Kościoła” tak ważny dla założycieli i założycielem różnych dróg życia konsekrowanego był otwarty na całe bogactwo Kościoła oraz posłuszeństwem wobec pasterzy Kościoła, a zwłaszcza następcy św. Piotra ${ }^{57}$.

Duchowość eklezjalna osób życia konsekrowanego zawsze przywołuje „wierność umysłu i serca wobec nauczania biskupów”, a ta z kolei często urasta do pewnego wzorca dla całego ludu Bożego Nowego Przymierza. W praktyce jest oczekiwana wzorcowa jedność między hierarchią i osobami życia konsekrowanego, np. w badaniach i nauczaniu teologii,

i wszerz. Życie w komunii staje się bowiem «znakiem dla świata i przyciągającą siłą, która prowadzi do wiary w Chrystusa. [...] W ten sposób owa komunia otwiera się na dzieło misyjne, więcej, sama staje się misją" (tenże, Adhortacja apostolska Vita consecrata, nr 46).

${ }^{54}$ KKK 1878.

${ }^{55}$ Jan Paweł II, Adhortacja apostolska Christifideles laici, nr 24.

${ }_{56}$ Por. Franciszek, Adhortacja apostolska Gaudete et exsultate, nr 15; Jan Paweł II, Kościół jako wspólnota bogata w charyzmaty, 24.06.1992, w: Katechezy Ojca Świętego Jana Pawła II. Kościót, Kraków-Ząbki 1999, s. 134-138; F. Mussner, La Lettera ai Galati, Brescia 1987, s. 580-587; G. Holotik, Die pneumatische Note der Moraltheologie. Ein ergänzender Beitrag zu gegenwärtigen Bemühungen im Rahmen der katholischen Sittlichkeitslehre, Wien 1984, s. 249-255; W. Barclay, Flesh and Spirit, London 1962, s. 63-76.

57 „Kościół bowiem jest zarazem komunią wiary i życia; jego normą jest «wiara, która działa poprzez miłość» (Ga 5,6). Żadne rozdarcie nie powinno zagrażać harmonii między wiarą a życiem; jedność Kościoła zostaje naruszona nie tylko przez chrześcijan, którzy nie doceniają wagi powinności moralnych, jakie nakłada na nich Ewangelia (por. 1 Kor 5,9-13)" (Jan Paweł II, Encyklika Veritatis splendor, nr 26). Por. Franciszek, Adhortacja apostolska Gaudete et exsultate, nr 60; Benedykt XVI, Encyklika Spe salvi, Città del Vaticano 2007, nr 14, 47; R. Schnackenburg, Nauka moralna Nowego Testamentu, Warszawa 1983, s. 338-342; H.-D. Wendland, Etica del Nuovo Testamento, Brescia 1975, s. 106-110; J. Kudasiewicz, Cechy specyficzne etosu biblijnego, w: W nurcie zagadnień posoborowych, t. 14: Chrześcijańska duchowość, red. B. Bejze, Warszawa 1981, s. 85-89. 
katechezie czy opiniach wyrażanych $\mathrm{w}$ mediach ${ }^{58}$. Warto także pamiętać, że „cały porządek hierarchiczny i struktura posług Kościoła też podlegają działaniu charyzmatów" 59 .

Duchowość „sentire cum Ecclesia” winna kształtować świadomość, życie i działanie osób życia konsekrowanego, mając zawsze na względzie fakt, że w rozeznawaniu powstania różnych wspólnot podstawowe było zatwierdzenie przez hierarchię ${ }^{60}$. Zawsze chodzi o harmonię z Kościołem i jego Magisterium ${ }^{61}$. Wierność Chrystusowi oznacza jednocześnie wierność Jego Kościołowi ${ }^{62}$.

Nie można w tym kontekście pominąć jedności bytowej oraz w podejmowanej misji życia konsekrowanego z laikatem i kapłaństwem sakramentalnym. Nie powinno to jednocześnie w niczym naruszać tożsamości poszczególnych stanów, a raczej sprzyjać jedności Kościoła i jego posłannictwa. Zatem „wszystko to należy czynić w komunii i dialogu z innymi podmiotami tworzącymi Kościół. Wyzwania misyjne są tak wielkie, że nie można ich skutecznie podjąć bez współpracy wszystkich członków Kościoła, zarówno w sferze rozeznania, jak i działania”63.

Dopiero wówczas wewnętrzna jedność wszystkich stanów życia i ich uległość autorytetowi apostolskiemu sprawiają, że „Kościół jest niejako sakramentem wewnętrznego zjednoczenia z Bogiem i jedności

${ }_{58}$ Por. Jan Paweł II, Adhortacja apostolska Vita consecrata, nr 46.

${ }_{59}$ Tenże, Duch Święty źródłem darów i charyzmatów w Kościele, 27.02.1991, w: Katechezy Ojca Świętego Jana Pawła II. Duch Święty, Kraków-Ząbki 1999, s. 267. „Rozwój wspólnoty kościelnej nie zależy jedynie od ustanowienia posług i sakramentów, lecz sprzyjają mu również nieprzewidziane i wolne dary Ducha Świętego, działającego także poza wszelkimi ustalonymi formami” (tenże, Kościół jako wspólnota bogata w charyzmaty, 24.06.1992, s. 134).

${ }^{60}$ „Ich żywotność musi zostać potwierdzona przez władzę kościelną, która winna przeprowadzić odpowiednie badania, pozwalające ocenić autentyczność celów inspirujących ich działalność, a zarazem uniknąć nadmiernego mnożenia się instytucji o podobnym charakterze, z czym związane jest ryzyko szkodliwego podziału na zbyt małe grupy" (Jan Paweł II, Adhortacja apostolska Vita consecrata, nr 12).

${ }_{61}$ Por. tenże, Adhortacja apostolska Vita consecrata, nr 13.

${ }^{62}$ Por. tenże, „Tak” Chrystusowi, „tak” Kościołowi. Homilia podczas spotkania z pielgrzymami na Jasnej Górze. 4.06.1997, „L'Osservatore Romano” 18 (1997), nr 7, s. $39-40$.

${ }^{63}$ Tenże, Adhortacja apostolska Vita consecrata, nr 74. 
całego rodzaju ludzkiego"64. Dopiero wobec takiej tożsamości Kościół w całym swym bogactwie będzie mógł stać się czytelną rzeczywistością dla świata ${ }^{65}$. Odczytanie sakramentalnego posłannictwa Kościoła wymaga jednak uznania, że to przede wszystkim Chrystus jest „Sakramentem Boga”, czyli znakiem zbawczym posłanym przez Ojca, który poznajemy dzięki działaniu Ducha Świętego ${ }^{66}$. W tym kontekście można też mówić o „sakramentalnej ewangelizacji”, która należy do „munus propheticum” Kościoła i pozwala lepiej zrozumieć prawdę Kościoła jako „społeczności profetycznej" ${ }^{67}$.

Duchowość „sentire cum Ecclesia” wpisana ze swej natury w życie konsekrowane ma odniesienie zarówno do Kościoła powszechnego, jak i do partykularnego. Ten rys komunijny w Kościele powszechnym jeszcze raz wskazuje, że wszystkie charyzmaty życia konsekrowanego są udzielane przez Ducha Świętego dla dobra Kościoła jako Mistycznego Ciała Chrystusa. Duch Święty zawsze staje jako życiodajna zasada Kościoła ${ }^{68}$. Ta misja życia konsekrowanego winna pozostawać w szczególnej więzi z misją każdego następcy św. Piotra ${ }^{69}$. Ta więź z Piotrem danego czasu stwarza twórcze szanse współpracy z różnymi Kościołami lokalnymi, gdzie osoby życia konsekrowanego spełniają konkretne zadania apostolskie, „doniosłą rolę".

Więź życia konsekrowanego z biskupem nie jest rezygnacją z bogactwa różnych charyzmatów i tożsamości danego instytutu, bowiem ta ostatnia ma moc Ducha sięgającą korzeni. Wszystko to winno raczej

${ }^{64} \mathrm{KK} 1$.

${ }^{65}$ Por. tenże, Adhortacja apostolska Vita consecrata, nr 46.

${ }_{66}$ Por. tenże, Encyklika Dominum et Vivificantem, nr 63-64; KKK 1118.

${ }^{67}$ Por. tenże, Świadectwo życia $w$ Chrystusie w Kościele - wspólnocie prorockiej. 20.05.1992, w: Katechezy Ojca Świętego Jana Pawła II. Kościół, s. 124-127.

${ }_{68}$ Por. tenże, Encyklika Dominum et Vivificantem, nr 2.

69 „Jak zauważyli Ojcowie synodalni, skuteczne głoszenie ewangelicznego orędzia, trwałe zakorzenienie się Kościoła w wielu regionach świata oraz rozkwit chrześcijaństwa, jako obserwujemy dziś w młodych Kościołach - wszystko to byłoby nie do pomyślenia bez wkładu licznych instytutów życia konsekrowanego i stowarzyszeń życia apostolskiego. Przez stulecia zachowały one mocna więź komunii z następcami św. Piotra, którzy zawsze znajdowali w nich wielkoduszną gorliwość misyjną i gotowość do służby, nawet za cenę heroicznej ofiary, jeśli wymagały tego okoliczności” (tenże, Adhortacja apostolska Vita consecrata, nr 47). 
być wzajemnym ubogaceniem ${ }^{70}$. Jednak instytuty życia konsekrowanego winny zachować swoją tożsamość i swoją autonomię ${ }^{71}$. Nie będą jednak prawdziwymi świadkami Chrystusa w świecie, jeżeli nie objawią swoim życiem tej nowości i oryginalności życia, które wyrasta $\mathrm{z}$ orędzia ewangelicznego i z wszczepienia w Chrystusa ${ }^{72}$.

\section{BOGACTWO ZADAŃ W KOŚCIELE}

Właśnie owo rozeznanie odpowiedzialności charyzmatów w Kościele lokalnym pozwala rozpoznać każdej wspólnocie życia konsekrowanego jej służebny charakter, jej wielorakie możliwości i właściwe wykorzystanie danego charyzmatu, zawsze w komunii z biskupem i na szerokim polu wielorakich posług ewangelicznych ${ }^{73}$. Dotyczy to m.in. ewangelizacji, katechizacji, życia parafialnego, pracy w grupach i wielorakich innych praktycznych przejawów obecności danej wspólnoty w Kościele lokal-

70 „Historia jest zatem dla Ludu Bożego drogą, którą ma on przejść w całości, aby dzięki nieustannemu działaniu Ducha Świętego ukazała się w pełni treść objawionej prawdy (por. J 16,13)" (Jan Paweł II, Encyklika Fides et ratio, nr 11). Por. I. de La Potterie, Le Paraclet, w: I. de La Potterie, S. Lyonnet, La vie selon l'Ésprit, conditio du chrétien, Paris 1965, s. 100-105; H. Muszyński, „Prawda” jako termin teologiczny w pismach św. Jana, w: Egzegeza Ewangelii św. Jana, red. F. Gryglewicz, Lublin 1976, s. 153-155; N. Lazure, Les valeurs morales de la théologie johannique (Évangile et Épitres, Paris 1965, s. 65-118; B. Prete, Dati e caratteristiche della antropologia giovannea, w: L'antropologia biblica e morale. Atti del Io Congresso dei Biblisti e Moralisti dell'Italia Meridionale (Castellamare 1-2 giugno 1971), Napoli 1972, s. 817-870.

71 „Diecezja, w której zabrakłoby życia konsekrowanego, nie tylko zostałaby pozbawiona licznych darów duchowych, miejsc służących poszukiwaniu Boga, specyficznych rodzajów apostolstwa i form duszpasterskich, ale mogłaby też w znacznej mierze utracić ducha misyjnego, jaki znamionuje większość instytutów” (Jan Paweł II, Adhortacja apostolska Vita consecrata, nr 48).

${ }^{72}$ Por. tenże, Encyklika Veritatis splendor, nr 88.

73 „Także w naszych czasach oglądamy rozkwit różnych charyzmatów wśród świeckich mężczyzn i kobiet. I choć otrzymują je poszczególne osoby, mogą uczestniczyć w nich także inni i w ten sposób zachowuje się ich ciągłość w czasie jako cenne i żywe dziedzictwo, tworzące pomiędzy ludźmi szczególne pokrewieństwo duchowe" (tenże, Adhortacja apostolska Christifideles laici, nr 24). 
nym $^{74}$. Zawsze należy pytać o dobro Kościoła, w kontekście współczesnych potrzeb. Samo życie konsekrowane nie jest środkiem apostolstwa ${ }^{75}$.

Komunia życia eklezjalnego dotyczy wszystkich instytutów życia konsekrowanego. Odnosi się to także do komunii misji kościelnej. Pewna bliskość umożliwia duchowe otwarcie na drugiego człowieka i jego wewnętrzne bogactwo. Uzdalnia do współpracy, pomaga w poznaniu siebie i sprzyja dojrzewaniu osobowemu ${ }^{76}$. W tym kontekście trzeba krzewić duchową komunię, „podkreślając jej znaczenie jako zasady wychowawczej wszędzie tam, gdzie kształtuje się człowiek i chrześcijanin, gdzie formują się szafarze ołtarza, duszpasterze i osoby konsekrowane, gdzie powstają rodziny i wspólnot"77.

Biskupa i wszystkich przełożonych winien ożywiać duch miłości Kościoła Chrystusowego o odpowiedzialność za jedność ludu Bożego w darach hierarchicznych i charyzmatycznych ${ }^{78}$. Jednocześnie „duchowość komunii” oznacza zdolność postrzegania drugiego człowieka jako kogoś bliskiego ${ }^{79}$. Dla pozytywnych owoców tej refleksji konieczne jest

${ }^{74}$ Por. tenże, Adhortacja apostolska Vita consecrata, nr 49.

75 Por. J. R. Bar, J. Kałowski, Prawo o instytutach życia konsekrowanego, Warszawa 1985, s. 160 .

${ }^{76}$ Por. KKK 2347.

77 Tenże, List apostolski Novo millennio ineunte, $\mathrm{nr} 43$.

78 Por. tenże, Adhortacja apostolska Vita consecrata, nr 49.

79 „Duchowość komunii to przede wszystkim spojrzenie utkwione w tajemnicy Trójcy Świętej, która zamieszkuje w nas i której blask należy dostrzegać także w obliczach braci żyjących wokół nas. Duchowość komunii to także zdolność odczuwania więzi z bratem w wierze dzięki głębokiej jedności mistycznego Ciała, a zatem postrzegania go jako «kogoś bliskiego», co pozwala dzielić jego radości i cierpienia, odgadywać jego pragnienia i zaspokajać jego potrzeby, ofiarować mu prawdziwą i głęboką przyjaźń. Duchowość komunii to także zdolność dostrzegania w drugim człowieka przede wszystkim tego, co jest w nim pozytywne, a co należy przyjąć i cenić jako dar Boży: dar nie tylko dla brata, który bezpośrednio go otrzymał, ale także «dar dla mnie». Duchowość komunii to wreszcie umiejętność «czynienia miejsca» bratu, wzajemnego «noszenia brzemion» (por. Ga 6,2) i odrzucania pokus egoizmu, które nieustannie nam zagrażają, rodząc rywalizację, bezwzględne dążenie do kariery, nieufność, zazdrość. Nie łudźmy się: bez takiej postawy duchowej na niewiele zdałyby się zewnętrzne narzędzia komunii. Stałyby się bezdusznymi mechanizmami, raczej pozorami komunii niż sposobami jej wyrażania i rozwijania" (Jan Paweł II, List apostolski Novo millennio ineunte, nr 43). Por. Franciszek, Adhortacja apostolska Gaudete et exsultate, nr 73. 
odpowiednie studium i szeroka refleksja naukowa, która odnosi się do wszystkich stanów i całego Kościoła partykularnego ${ }^{80}$.

W duchowości komunii „sentire cum Ecclesia” osoby podążające drogą życia konsekrowanego winny realizować siebie „W całkowitej uległości wobec Bożych natchnień i zgodnie z rozeznaniem Kościoła” ${ }^{\text {. }}$. Tutaj staje m.in. wielkie bogactwo zaangażowania misyjnego, które winien podjąć Kościół, a zwłaszcza ewangelizacja współczesnego świata.

Zatem najpierw pierwsze przepowiadanie Chrystusa aż po krańce świata (por. Mt 28,18-20), które winno uwzględniać elementy inkulturacji. Nauka o chrześcijańskich wartościach w kulturze ma za podstawę wcielenie Syna Bożego i Jego zbawczą misję. Aksjologia, którą proponuje kultura, skupia się na fakcie, że Jezus Chrystus jest Boskim Prawodawcą ${ }^{82}$.

Natomiast skuteczność nowej ewangelizacji w znacznym stopniu zależy od świętości i świadectwa jej głosicieli, a więc wierności Ewangelii i Chrystusowi. „Nowa ewangelizacja wymaga od osób konsekrowanych pełnej świadomości teologicznego sensu wyzwań naszej epoki”" ${ }^{83}$. Przecież przez grzech konkretnego chrześcijanina „cały Kościół został obrażony i zraniony" ${ }^{\text {"; }}$ z powodu grzechu za mało świeci oblicze Kościoła wobec tych, którzy na niego patrzą ${ }^{85}$.

„Sentire cum Ecclesia” wskazuje także na świat ubogich i promocję sprawiedliwości społecznej oraz opiekę nad chorymi. Pełni wiary ochrzczeni zawsze odnajdywali w ubogich Chrystusa. Zaś osoby życia konsekrowanego szczególnie oddawały się takiemu Chrystusowi na służbę miłości, pamiętając, że cokolwiek czynią dla ubogich i chorych, czynią dla samego Jezusa w bezgranicznej miłości (por. Mt 25,31-46) ${ }^{86}$.

${ }^{80}$ Por. Jan Paweł II, Adhortacja apostolska Vita consecrata, nr 50.

81 Tenże, Adhortacja apostolska Vita consecrata, nr 37.

82 Por. Franciszek, Adhortacja apostolska Gaudete et exsultate, nr 129; Jan Paweł II, Encyklika Veritatis splendor, nr 2, 6, 12, 23. Por. G. Bonnet, Au nom de la Bible et de l'Évangile, quelle morale, Paris 1978, s. 82-85; W. Vogels, God's Universal Covenant. A Biblical Study, Ottawa 1979, s. 134-147; J.-M. Faux, La foi du Nouveau Testament, Bruxelles 1977, s. 375-380; C. Caffarra, Viventi in Cristo, Milano 1981, s. 22-27.

${ }^{83}$ Jan Paweł II, Adhortacja apostolska Vita consecrata, nr 81. Por. tenże, Adhortacja apostolska Vita consecrata, nr 76-79.

${ }^{84}$ Tenże, Adhortacja apostolska Reconciliatio et paenitentia, $\mathrm{nr} 31$.

${ }^{85}$ Por. tenże, Adhortacja apostolska Reconciliatio et paenitentia, nr 12.

${ }^{86}$ Por. Franciszek, Adhortacja apostolska Gaudete et exsultate, nr 96, 110; 
Stając wobec świata i Kościoła, radykalizm rad ewangelicznych ma także jaśnieć w pełnieniu misji prorockiej, „przemawiając w imieniu Boga nawet do Pasterzy Kościoła" ${ }^{\text {" }}$. Współcześnie ważne jest zauważenie „areopagów misji”"88. Jako podstawowe należą do nich: twórcza obecność w wychowaniu ludzkości w duchu Ewangelii, ewangelizacja kultury i środków społecznego przekazu i służba na rzecz jedności chrześcijan i wszystkich poszukujących Boga. Zwłaszcza środki przekazu są głównym narzędziem informacyjnym i formacyjnym, przewodnikiem zachowań indywidulanych i społecznych ${ }^{89}$.

W dziejach misyjnej posługi ważne jest wskazanie na owocowanie przelanej krwi, na świadectwo męczeństwa ${ }^{90}$. W ten sposób świadkowie w Kościele na wzór Jezusa są doświadczani jak złoto, które „próbuje się w ogniu” (1 P 1,7) ${ }^{91}$. Trzeba jednak zauważyć, że ani męczeństwo krwi,

Jan Paweł II, Adhortacja apostolska Vita consecrata, nr 82-83. Por. A. Feuillet, Le caractère universel du jugement et la charité sans froniières en Mt 25,31-46, „Nouvelle revue theologique" 102 (1980), s. 179-196; V. K. Agbanou, Le discours eschatologique de Matthieu 24-25; tradition et rédaction, Paris 1983, s. 170-179; J. Gnilka, Il Vangelo di Matteo, t. 2, Brescia 1991, s. 532-554.

87 Jan Paweł II, Adhortacja apostolska Vita consecrata, nr 84.

88 „Tych «areopagów» jest dziś wiele i są bardzo różne. Są to wielkie tereny współczesnej cywilizacji i kultury, polityki i ekonomii. Im bardziej Zachód odrywa się od swych chrześcijańskich korzeni, tym bardziej staje się terenem misyjnym, w znaczeniu wielorakich «areopagów»" (tenże, List apostolski Tertio millennio adveniente, nr 57).

${ }^{89}$ Por. Jan Paweł II, Encyklika Redemptoris missio, nr 37.

90 „W naszym stuleciu, podobnie jak w innych epokach dziejów, konsekrowani mężczyźni i kobiety dali świadectwo o Chrystusie Panu, składając dar z własnego życia. Wielka ich rzesza - chroniąc się w katakumbach przed prześladowaniami reżimów totalitarnych lub przed przemocą, zmagając się z trudnościami, jakie stawiano ich działalności misyjnej, służbie ubogim. Opiece nad chorymi i odrzuconymi - przeżyła i przeżywa swoją konsekrację przez długotrwałe i heroiczne znoszone cierpienie, a często przez przelanie własnej krwi, upodobniwszy się całkowicie do ukrzyżowanego Chrystusa. Kościół uznał już oficjalnie świętość niektórych z nich i czci ich jako męczenników Chrystusa” (tenże, Adhortacja apostolska Vita consecrata, nr 86).

${ }^{1}$ Por. E. G. Selwyn, Eschatology of 1 Peter, w: The Background of the New Testament and its Eschatologu. Studies in honour C. H. Dodd, Cambridge 1964, s. 394-401; F. Gryglewicz, Eschatologiczne aspekty listów katolickich, w: Materiały pomocnicze do wykładów z biblistyki, t. 8: Biblia o przyszłości, red. L. Stachowiak, R. Rubinkiewicz, Lublin 1987, s. 109-116; E. G. Selwyn, The First Epistle of St. Peter, London 1958, s. 247-258. 
ani tortura nie są jeszcze obiektywnym dowodem na obiektywną prawdę, której ktoś w ten sposób chce dać świadectwo - „świadczący udowadnia przez świadectwo krwi tylko to, że wartość, za którą oddaje swoje życie, jest dla niego wartością wyższą od życia, a może nawet uważa on ją za

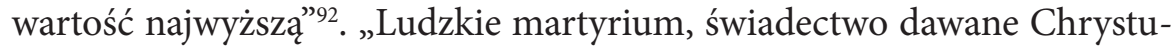
sowi za cenę prześladowań, a nawet śmierci, ma podstawowe znaczenie dla życia Kościoła. W sposób szczególny uobecnia ono Bożą tajemnicę, którą Kościół żyje i ożywia świat"93.

Kościół, kierując się duchem Ewangelii, wkładał duże zaangażowanie $\mathrm{w}$ wychowanie. Przecież wielu fundatorów dróg życia konsekrowanego wskazywało na zaangażowanie w posługę wychowawczą, wskazując właśnie na taki charyzmat. Także i dziś pilnie potrzebne jest zaangażowanie na polu edukacyjnym i kulturowym. To wręcz znak czasu. Stąd konieczność zmian w celu przystosowania do się do warunków działania w społeczeństwie przemysłowym, technicznym i demokratycznym ${ }^{94}$.

Kościół nie narzuca niewierzącym „poglądów wynikających z wiary, ale interpretuje i chroni wartości zakorzenione w samej naturze istoty ludzkiej. W ten sposób praktyka miłosierdzia stanie się w konsekwencji także służbą kulturze, polityce, gospodarce i rodzinie, aby wszędzie były przestrzegane podstawowe zasady, od których zależy los człowieka i przyszłość cywilizacji”"95.

Dziś pilnie potrzebne jest tworzenie kultury ludzkiej na miarę świata Ewangelii. „Każdy człowiek, każdy naród, każda kultura i cywilizacja mają swoją rolę do wypełnienia i swoje miejsce w tajemniczym planie Boga i powszechnej historii zbawienia" ${ }^{\text {96 }}$. Zatem Kościół, a w nim

${ }^{92}$ H. U. von Balthasar, Świadectwo i wiarygodność, „Communio” 9 (1989), nr 6, s. 107.

${ }^{3}$ Jan Paweł II, Szczególna postać teologii wyzwolenia w Europie. Przemówienie do uczestników Kongresu Teologów Europy Środkowo-Wschodniej, Częstochowa, 15.08.1991, „L'Osservatore Romano” 12 (1991), nr 8, 35.

94 Por. H. P. M. Godijn, Życie zakonne w naszych czasach, w: Ludzie - wiara - Kościół. Analizy socjologiczne, Warszawa 1966, s. 242-260; E. Pin, Apostolskie zgromadzenia zakonne wobec przemian socjo-kulturowych. Rozważania socjologiczne, w: Ludzie - wiara - Kościót. Analizy socjologiczne, s. 287-307.

${ }^{95}$ Jan Paweł II, List apostolski Novo millennio ineunte, $\mathrm{nr} 51$.

96 Tenże, Encyklika Slavorum Apostoli, Città del Vaticano 1985, nr 7. 
życie konsekrowane, zabiega o kulturę otwartą na drugiego człowieka, niezależnie od tego, do jakiego ludu czy narodu on należy ${ }^{97}$.

Środki komunikacji społecznej są tutaj narzędziami ewangelizacji. Instytuty życia konsekrowanego winny w tym kontekście rozeznawać nowe znamiona jedności chrześcijan, dialogu międzyreligijnego i poszukiwania Boga przez człowieka. Tutaj szczególną rolę do spełnienia mają osoby życia konsekrowanego, a więc znak radykalizmu świadczenia o Chrystusie, o Jego dziele zbawienia. To zaś wpisane jest w czasach eschatologicznych w posługę Kościoła, pielgrzymującego ludu Nowego Przymierza ${ }^{98}$.

Kościół święty zawsze i z ogromnym uznaniem patrzy na doniosłość życia konsekrowanego. Dotyczy to zarówno przeszłości, jak i teraźniejszości, a jednocześnie także nadziei ku przyszłości. To nie tylko dzieła i znaki posługi, ale przede wszystkim współtworzenie Kościoła, w ramach trzech stanów tej wspólnoty. To jest de facto współkonstytuowanie Kościoła, bo życie konsekrowane przynależy do jego struktury. Ma w nim źródło, istnienie i ostatecznie jest dla Kościoła. Będąc z Kościoła, w Kościele i dla Kościoła stan życia konsekrowanego powołany jest do życia duchowością komunii „sentire cum Ecclesia”.

Kościół zawsze z wielkim szacunkiem i miłością wypowiada się o życiu konsekrowanym, a zwłaszcza o kobietach, które podążają tą drogą radykalizmu ewangelicznego: „Dziękujmy ci, kobieto konsekrowana, która na wzór największej z kobiet, Matki Chrystusa - Słowa Wcielonego, otwierasz się ulegle i wiernie na Miłość Bożą, pomagając Kościołowi i całej ludzkości dawać Bogu «oblubieńczą» odpowiedź, wyrażającą się w przedziwnej komunii, w jakiej Bóg pragnie pozostawać ze swoim stworzeniem. Dziękujmy ci, kobieto, za to, że jesteś kobietą! Zdolnością poznania cechującą twą kobiecość wzbogacasz właściwe zrozumienie świata i dajesz wkład w pełną prawdę o związkach między ludźmi”"99.

\footnotetext{
97 Por. tenże, Adhortacja apostolska Ecclesia in Europa, nr 100-103.

98 Por. Jan Paweł II, Adhortacja apostolska Vita consecrata, nr 96-103.

99 Tenże, List do kobiet A ciascuna di voi, Città del Vaticano 1995, nr 2.
} 


\section{BIBLIOGRAFIA}

Agbanou V. K., Le discours eschatologique de Matthieu 24-25; tradition et rédaction, Paris 1983.

Balthasar von, H. U., Świadectwo i wiarygodność, „Communio” 9 (1989), nr 6, s. 107-114. Bar J. R., Kałowski J., Prawo o instytutach życia konsekrowanego, Warszawa 1985.

Barclay W., Flesh and Spirit, London 1962.

Benedykt XVI, Encyklika Spe salvi, Città del Vaticano 2007.

Bonnet G., Au nom de la Bible et de l'Evangile, quelle morale, Paris 1978.

Bouwmeester W., L'alleanza nella Bibbia, Bari 1972.

Bultmann R., Theologie des Neuen Testaments, Tübingen 1977.

Caffarra C., Viventi in Cristo, Milano 1981.

Ciardi F., Spunti di lettura ecclesiologica della „Vita consecrata”, w: Vita consecrata. Una prima lettura teologica, Milano 1996, s. 55-105.

Collange J.-F., De Jésus à Paul: L’etique du Nouveau Testament, Genève 1980.

Denzinger H., Schonmetzer A., Enchiridion symbolorum, definitionum et declarationum de rebus fidei et morum, Freiburg im Br. 1976.

Durrwell F.-X., „:Siete stati chiamati”, w: Chiamati alla liberta. Saggi di teologia morale in onore di Bernard Häring, red. H. Boelaars, R. Tremblay, Roma 1980, s. 7-22.

Faux J.-M., La foi du Nouveau Testament, Bruxelles 1977.

Feuillet A., Le caractère universel du jugement et la charité sans frontières en Mt 25,31-46, „Nouvelle revue theologique” 102 (1980), s. 179-196.

Franciszek, Adhortacja apostolska Gaudete et exsultate, Città del Vaticano 2018.

Franciszek, Encyklika Lumen fidei, Città del Vaticano 2013.

Gnilka J., Il Vangelo di Matteo, t. 2, Brescia 1991.

Godijn H. P. M., Życie zakonne w naszych czasach, w: Ludzie - wiara - Kościót. Analizy socjologiczne, Warszawa 1966, s. 242-260.

Grabska S., Comment lire les lettres de Saint Paul pour utiliser son enseignement dans la théologie morale contemporaine, „Studia Moralia” 13 (1975), s. 41-65.

Gryglewicz F., Eschatologiczne aspekty listów katolickich, w: Materiały pomocnicze do wykładów z biblistyki, t. 8: Biblia o przyszłości, red. L. Stachowiak, R. Rubinkiewicz, Lublin 1987, s. 105-126.

Holotik G., Die pneumatische Note der Moraltheologie. Ein ergänzender Beitrag zu gegenwärtigen Bemühungen im Rahmen der katholischen Sittlichkeitslehre, Wien 1984.

Jan Paweł II, Adhortacja apostolska Catechesi tradendae, Città del Vaticano 1979.

Jan Paweł II, Adhortacja apostolska Christifideles laici, Città del Vaticano 1988.

Jan Paweł II, Adhortacja apostolska Ecclesia in Africa, Città del Vaticano 1995.

Jan Paweł II, Adhortacja apostolska Ecclesia in Europa, Città del Vaticano 2003.

Jan Paweł II, Adhortacja apostolska Pastores dabo vobis, Città del Vaticano 1992.

Jan Paweł II, Adhortacja apostolska Reconciliatio et paenitentia, Città del Vaticano 1984.

Jan Paweł II, Adhortacja apostolska Redemptoris donum, Città del Vaticano 1984.

Jan Paweł II. Adhortacja apostolska Vita consecrata. Città del Vaticano 1996. 
Jan Paweł II, Duch Święty źródłem darów i charyzmatów w Kościele, 27.02.1991, w: Katechezy Ojca Świętego Jana Pawła II. Duch Święty, Kraków-Ząbki 1999, s. 263-267.

Jan Paweł II, Encyklika Dives in misericordia, Città del Vaticano 1980.

Jan Paweł II, Encyklika Dominum et Vivificantem, Città del Vaticano 1986.

Jan Paweł II, Encyklika Evangelium vitae, Città del Vaticano 1995.

Jan Paweł II, Encyklika Fides et ratio, Città del Vaticano 1998.

Jan Paweł II, Encyklika Redemptor hominis, Città del Vaticano 1979.

Jan Paweł II, Encyklika Redemptoris missio, Città del Vaticano 1990.

Jan Paweł II, Encyklika Slavorum Apostoli, Città del Vaticano 1985.

Jan Paweł II, Encyklika Ut unum sint, Città del Vaticano 1995.

Jan Paweł II, Encyklika Veritatis splendor, Città del Vaticano 1993.

Jan Paweł II, Kościół jako wspólnota bogata w Charyzmaty, 24.06.1992, w: Katechezy Ojca

Świętego Jana Pawła II. Kościół, Kraków-Ząbki 1999, s. 134-138.

Jan Paweł II, List apostolski Mulieris dignitatem, Città del Vaticano 1988.

Jan Paweł II, List apostolski Novo millennio ineunte, Città del Vaticana 2001.

Jan Paweł II, List do kobiet A ciascuna di voi, Città del Vaticano 1995.

Jan Paweł II, List do Młodych Parati semper, Città del Vaticano 1985.

Jan Paweł II, Szczególna postać teologii wyzwolenia w Europie. Przemówienie do uczestników Kongresu Teologów Europy Środkowo-Wschodniej, Częstochowa, 15.08.1991, „L'Osservatore Romano” 12 (1991), nr 8, s. 33-36.

Jan Paweł II, Świadectwo życia w Chrystusie w Kościele - wspólnocie prorockiej, 20.05.1992, w: Katechezy Ojca Świętego Jana Pawła II. Kościót, Kraków-Ząbki 1999, s. $124-127$.

Jan Paweł II, „Tak” Chrystusowi, „tak” Kościołowi. Homilia podczas spotkania z pielgrzymami na Jasnej Górze, 4.06.1997, „L'Osservatore Romano” 18 (1997), nr 7, s. $39-40$.

Jan Paweł II, Trudny dar wolności. Homilia podczas Mszy św. w kaplicy Cudownego Obrazu. Częstochowa, 13.06.1987, „L'Osservatore Romano” 8 (1987), nr 5 bis, s. 9.

Jan Paweł II, Wymiary życia konsekrowanego. 26.10.1994, w: Katechezy Ojca Świętego Jana Pawła II, Kościót. Kraków-Ząbki 1999, s. 411-414.

Katechizm Kościoła Katolickiego, Poznań 2002.

Kongregacja Instytutów Życia Konsekrowanego i Stowarzyszeń Życia Apostolskiego, Rozpoczać na nowo od Chrystusa. Odnowione zaangażowanie życia konsekrowanego w trzecim tysiącleciu. Instrukcja, Poznań 2002.

Kruszyłowicz B., Wymiar eklezjalny życia konsekrowanego, w: Communio consecrata, red. K. Wójtowicz, Kraków 2002, s. 116-125.

Kudasiewicz J., Cechy specyficzne etosu biblijnego, w: W nurcie zagadnień posoborowych, t. 14: Chrześcijańska duchowość, red. B. Bejze, Warszawa 1981, s. 61-88.

Ladaria L. F., Antropologia teologica, Roma-Casale Monferrato 1986.

La Potterie I. de, Le Paraclet, w: I. de La Potterie, S. Lyonnet, La vie selon l'Ésprit, conditio du chrétien, Paris 1965, s. 85-105. 
Lazure N., Les valeurs morales de la théologie johannique (Évangile et Épitres), Paris 1965.

Liszka P., Charyzmatyczna moc życia zakonnego, Wrocław 1996.

Mongillo D., Stałe nawrócenie i asceza. Ponowne odkrycie i nowa ocena terminów, w: Perspektywy i problemy teologii moralnej, red. G. Angelini i inni, Warszawa 1982, s. 167-181.

Mussner F., La Lettera ai Galati, Brescia 1987.

Muszyński H., „Prawda” jako termin teologiczny w pismach św. Jana, w: Egzegeza Ewangelii św. Jana, red. F. Gryglewicz, Lublin 1976, s. 141-159.

Parzyszek C., Przesłanie Jana Pawła II o życiu konsekrowanym, „Ateneum Kapłańskie” 149 (2007), z. 1 (590), s. 67-82.

Paweł VI, Adhortacja apostolska Evangelica testificatio, Città del Vaticano 1971.

Pin E., Apostolskie zgromadzenia zakonne wobec przemian socjo-kulturowych. Rozważania socjologiczne, w: Ludzie - wiara - Kościót. Analizy socjologiczne, Warszawa 1966, s. 287-307.

Prete B., Dati e caratteristiche della antropologia giovannea, w: L'antropologia biblica e morale. Atti del Io Congresso dei Biblisti e Moralisti dell'Italia Meridionale (Castellamare 1-2 giugno 1971), Napoli 1972, s. 817-870.

Schnackenburg R., Nauka moralna Nowego Testamentu, Warszawa 1983.

Selwyn E. G., Eschatology of 1 Peter, w: The Background of the New Testament and its Eschatologu. Studies in honour C. H. Dodd, Cambridge 1964, s. 532-554.

Selwyn E. G., The First Epistle of St. Peter, London 1958.

Sobór Watykański II, Konstytucja dogmatyczna o Kościele Lumen gentium, w: Konstytucje, dekrety, deklaracje, Poznań 2002, s. 104-163.

Sobór Watykański II, Konstytucja duszpasterska o Kościele w świecie współczesnym Gaudium et spes, w: Konstytucje, dekrety, deklaracje, Poznań 2002, s. 526-606.

Tremblay R., L’,innalzamento” del Figlio, fulcro della vita morale, Roma 2001.

Vogels W., God's Universal Covenant. A Biblical Study, Ottawa 1979.

Wattiaux H., Engagement de Dieu et fidélité du chrétien. Perspectives pour une théologie morale fondamentale, Louvain-la-Nevue 1979.

Weismayer J., Petnia życia. Zarys historii i teologii chrześcijańskiej duchowości, Kraków 1993.

Wendland H.-D., Etica del Nuovo Testamento, Brescia 1975. 